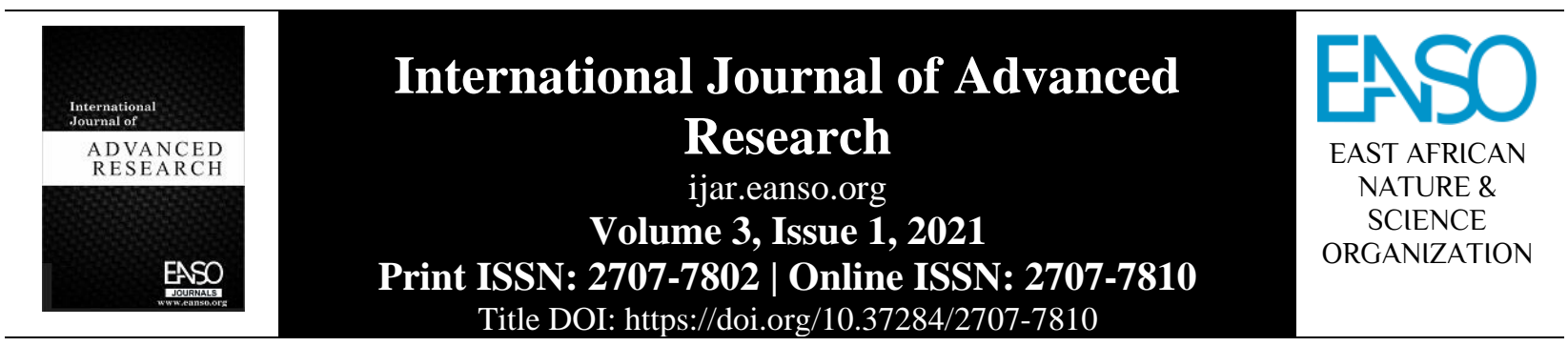

Original Article

\title{
Role Model Choice Habits of Primary School and University Students in An International Perspective.
}

\author{
Dr. Gabriella Hideg ${ }^{l} *$ \\ ${ }^{1}$ University of Pécs, 48-as tér 1, 7622 Hungary. \\ * ORCID: https://orcid.org/0000-0002-2916-1145; Author email: gabriella.hideg@etk.pte.hu.
}

Article DOI: https://doi.org/10.37284/ijar.3.1.400

Publication Date: ABSTRACT

02 September 2021 By the XXI century, we are always online thanks to the available modern telecommunication tools, so certain concepts, results, and value systems are Keywords: therefore revalued. This change, which involves loss of value as well, is present Role Model, in all areas of life and has an impact on the morality and value perception of the Values, growing generation. The purpose of the study is on the one hand to present and analyse the changes in values of today's society. On the other hand, its purpose is Change in Value, to give a picture of the role model choices of today's young people. As a test Internationalization. method, we used a questionnaire survey method besides exploring the domestic and international literature. A total of 687 people participated in the survey. The study was conducted with the participation of six countries, including four in Europe - Hungary, Ukraine, Romania, and Serbia - and two outside Europe Malaysia and Kenya. Our hypotheses were: H1: It is assumed that most of the young people have an athlete role model; H2: It is assumed that in Kenya and Malaysia there is a significantly higher proportion of those who choose athlete role models and they are chosen along with positive values; H3: It is assumed that, due to social, economic, and cultural disparities, I can show significant differences in the choice of role models for young people surveyed in Central and Eastern European and non-European countries. As a result, the habits of athlete role model choice among the interviewed young people of six countries become comparable. We get a clearer picture of the values along which young people choose an orientation person.

\section{APA CITATION}

Hideg, G. (2021). Role Model Choice Habits of Primary School and University Students in An International Perspective. International Journal of Advanced Research, 3(1), 115-129. https://doi.org/10.37284/ijar.3.1.400

\section{CHICAGO CITATION}

Hideg, Gabriella. 2021. "Role Model Choice Habits of Primary School and University Students in An International Perspective". International Journal of Advanced Research 3 (1), 115-129. https://doi.org/10.37284/ijar.3.1.400.

115 | This work is licensed under a Creative Commons Attribution 4.0 International License. 
HARVARD CITATION

Hideg, G. (2021) "Role Model Choice Habits of Primary School and University Students in An International Perspective", International Journal of Advanced Research, 3(1), pp. 115-129. doi: 10.37284/ijar.3.1.400.

\section{IEEE CITATION}

G. Hideg, "Role Model Choice Habits of Primary School and University Students in An International Perspective", IJAR, vol. 3, no. 1, pp. 115-129, Sep. 2021.

\section{MLA CITATION}

Hideg, Gabriella. "Role Model Choice Habits of Primary School and University Students in An International Perspective". International Journal of Advanced Research, Vol. 3, no. 1, Sep. 2021, pp. 115-129, doi:10.37284/ijar.3.1.400.

\section{INTRODUCTION}

By the XXI. century, we are always online every minute thanks to modern telecommunications devices, and this is one of the reasons why certain concepts, results, and values are being re-evaluated. This change, which also involves the impairment, is present in all areas of life, and as a result, it can be felt that sport and sports results have taken on a new dimension. The present and future of a sport are increasingly determined by how much it can be sold, how much it can be broadcast, how well it can adapt to the expectations of the "entertainment industry". In addition, it has grown into an economic and business industry (sportswear, sports equipment, media).

Our theoretical background is limited to the description of diverse, short literature on hypotheses. In formulating our hypotheses, we started from the Hungarian and Diaspora Hungarians, as well as the social and economic cultural differences between Kenya and Malaysia.

\section{Changes in Role Model and Role Model Selection}

Our adult qualities, values, and relationships with the world are greatly influenced by how the main sources of socialization affected us in our childhood. According to László, these three sources of socialization are the family, as well as the immediate circle of acquaintances, the school, and now the third is the social knowledge, experience, and value systems delivered to children through the means of mass communication. It is well known that the role of the latter is growing more and more as the role of the media is also growing in people's lives. So, we gain most of our experience not personally, but indirectly, through the media, and at the same time, society is becoming more and more complex. Today's teenagers, who are online almost every moment, are especially sensitive and receptive to all of this.

Mihály described the beginning of the XXI. century as an age affected by the crisis of values and the devaluation of traditional value systems in her study, in which she reviewed children's role models based on research conducted in different countries. Before reviewing and comparing research results, it is important to clarify what/who the role model is. So, a role model is someone who, because of some trait or deed, is looked up to and considered to be followed, and in many cases, people even imitate his actions. We would note that a role model cannot be just a living or already dead person. When we think of younger children, a fictional person, such as a fairy tale figure, can also be followed.

International research on changing the choice of role models is very wide-ranging. According to Mihály, who examined a significant part of international research, this research highlighted the growing role of the media in the choice of role models. On the one hand, the results are in line with the results of Hungarian researchers, and on the other hand, they reinforce the hypothesis that ideals have changed significantly with the spread of the media. Two trends can be observed, on the one hand, the chosen role models are present in the media - that is the vast majority are athletes, pop stars, actors - and on the other hand the proportion of those who do not have role models is increasing, emphasizing the importance of their unique personality. Let us first examine the person of the role model and the trait/mediated value by which young people around the world choose an orientation person.

Teigen et al. repeated Reymert's previous research and examined the changes that have taken place over the past ninety years. Based on the results of 
the repetition of the mentioned Norwegian research, it can be concluded that the adolescents who lived at the turn of the XIX. and XX. centuries chose their role models from the greats of history and literature, while the heroes of their contemporaries today came from the worlds of sports, pop music, and cinema.

Examining the results of Hill and Havighurst and Mcdonald, the previously mentioned tendency for young people to choose an example for themselves from television is further strengthened. Hill concluded in his research of 1930 that adolescents are increasingly choosing real contemporary personalities and those like George Washington are pushed into the background. In 1955, it was found by Havighurst and McDonald that the emergence of previously popular historical, literary characters as role models now accounts for only $10 \%$. Teigen et al. draw attention to the shortcomings of their own and their colleagues' previous studies that responses in which young people did not have a role model have been present in the past, but these were categorized as uninterpretable or otherwise.

Following the collection of Mihály, she draws attention to further research. In László's research of 1998, 90\% of the respondents answered questions related to the choice of role models. More than half of the respondents named a specific person as a role model, they chose it primarily from their family and their immediate environment. $10 \%$ who did not name a role model justified their decision. They can be divided into four categories based on their answers, these are indeterminate ("I do not know"), confident ("I want to be myself", "I go my own way"), self-fulfilling ("I am good the way I am" or "I am perfect") and the demanding (they would create role models from several people, values were chosen, but they have not found all of these in one person yet).

They also examined the characteristics based on which young people choose a role model for themselves, where they could choose from 40 options. László divided the values into three groups. The first is the group of values related to the family factor (empathy, diligence, knowledge), the second to the media factor (popularity, professional recognition), and the third to the school (patriotism, prudence). In addition, it was stated that $50 \%$ of the respondents choose a value that is organized around the individual, $28 \%$ choose values expressing reciprocity, and the remaining $22 \%$ consider aspects oriented towards the community and social coexistence important.

Another interesting fact of the study is that $18.3 \%$ of the respondents chose the uniqueness of personality, $16.2 \%$ chose knowledge, $14.3 \%$ chose self-realization, and $11.9 \%$ chose the possibility of professional competence and talent. Thus, it can be said that for $60.5 \%$ of the respondents, these values are the most important when choosing a role model. Negative values such as aggression were chosen by $1.1 \%$ of respondents.

The study of 2000 did not show a marked difference in the results; however, a different trend was observed. Young people still chose their role model from the family, from relatives, so the family as a category was even more dominant. In contrast, the proportion of role models selected based on the values conveyed by the school decreased, but persons selected from the media appeared among the role models.

The study of 2007 marked a turning point in young people's lives when media education began in the classrooms, so researchers interviewed students twice. Once before the start of education and a second time at the end of education. In doing so, they examined the impact of the internet on young people's value judgments and selecting role models. $47 \%$ of the interviewed students chose a parent or relative as a role model, $15 \%$ chose an athlete, $14 \%$ a celebrity (actor or musician), $21 \%$ chose a role model from other categories, including, for example, a teacher. In the second round, after media education, the results show that no significant change has taken place. However, the role of the family has decreased, and in parallel, we can talk about an increase in other categories, like athletes or actors. All this is due to the fact that with the use of the internet, the world has widened in front of young people. Positive human qualities and inner qualities are still considered important as a justification for their choice of role models. Similar to the results of the research of 1998, some did not name a role model (17\%), list their uniqueness and specialness among their reasons, because they do not want to compare themselves to anyone because they are unique and satisfied with themselves. 
Looking at the results of the survey of 2009, the following findings can be made: in 1998 the proportion of young people who could not or did not choose a role model was $10 \%$, in 2007 this figure reached $17 \%$, in 2009 it was $43 \%$. Regarding the person of the role model, we can state that the proportion of role models chosen from parents, relatives, acquaintances, or friends from the immediate environment was $40 \%$ in 2009 , and $16 \%$ were those who chose a role model for themselves from the media. Personalities like Messi, Beckham, or Ferenc Puskás from the world of sports appear here, and if we look at pop stars, Lady Gaga, Britney Spears, and Rihanna appear, the world of cinema is "represented" by Chuck Norris and Vin Diesel. If we examine the lesser-known but classic role models, businessman Bill Gates or the Hungarian master hairdresser Tamás Zsidr will appear. But young people consider Anita Gorbicz, Mary Notar or Janos Galvolgyi to be role models too.

László also examined the choice of role models as a function of internet usage habits. As a result, a larger number of experienced Internet users choose role models from the media, and the proportion of those who spend less time on the World Wide Web continues to name their parents as an example to follow. Overall, based on László's research, it can be said that parents are still a sure point for young people in the increased information flow.

Like László, Berta also examined the role models of young people. She divided the results into three groups. The first category was family, the second category was school, the third was media, and there was a fourth, other category, such as familiar adults. $31.6 \%$ of respondents stated that they had no role model, $23.9 \%$ chose from their family, and $23.5 \%$ from the media. Only $1.7 \%$ of the respondents chose a role model from school. Compared to László's research, there is still a tendency that the majority of young people, in this case, $31.6 \%$, do not have a role model, but we think that the $14.5 \%$ who did not answer this question should be included here too. It can be seen that the role of parents and the family is still high as in the past, but it is also worth mentioning the tendency that the media is becoming more and more dominant and young people choose a role model from there as a result.
In pilot research, Pap examined the role models of young people in addition to the media consumption habits of the 10-14-year-olds. Although young people have a good time in the virtual world, in the world of the internet, they use it consciously, they get their information from there, nevertheless, parents and siblings as role models still play an important role in their role model selection, but the proportion of those who consider media stars as role models are increasing. Today's 10-14-year-olds mention the winner of the X-Factor, Andi Tóth, the well-known star of the Disney Channel, Selena Gomez, as role models, but Krisztián Berki also appears as a role model (unfortunately not the athlete, gymnast Olympic champion, but the daily docu-reality actor). In addition, the number of young people who do not have role models remains significant, as before, they mention as a reason that they do not want to be compared to anyone, they want to be themselves.

Role model studies also cover gender distribution. Examining the gender difference, we can state the following: boys rather named men, athletes, pop stars, television actors, and actors, while girls named movie stars, pop stars, and relatives of the opposite sex.

Biskup and Pfister came to a similar conclusion, as their research subjects, most notably boys, often chose athletes as role models. They also conducted interviews that revealed that the majority of boys choose athletes and action heroes because they consider them aggressive, strong, and capable of anything. In contrast, girls prefer the movie or pop stars because they like their appearance or social behaviour.

Ewens and Lashuk observed that male athletes are much more often chosen as role models than women. And Lines' research showed that girls are much more likely to choose role models from magazines or the television screen. Jones and

Ilic describes two ways to identify with an athlete role model. One is identification, the essence of which is that for the fan the athlete as a brand will be desirable. The other way to identify is internalization that is to take over the properties of the role model and to shape our lives based on these. 
Overall, it can be stated that the changes in the choice of role models are not Hungarian, Norwegian, or Finnish characteristics, but an international trend, which is also proved by the studies presented above. International and domestic research results reinforce the trend that increasing access to media and the internet is having an increasing impact on the lives and value judgments of today's youth. If families and the education system can manage the negative effects of technological advances on young people's values, although priorities may change, they will not lead to personality distortions. We believe the problem occurs when and where the parent is also influenced by the media and tries to imitate the lifestyles of stars and celebrities, thus showing a distorted picture to the next generation.

What are we worried about? Non-traditional values are represented by athletes, musicians, actors, media stars. Looking out of Europe it can be seen that the moral and value loss in our societies, as we mentioned in our introduction, is not only a European characteristic but rather a global trend. In education, value orientation is becoming more and more emphasized. A good example of this is the case of Malaysia and Kenya, but from the point of view of Hungary, we must not forget the education on religion and ethics recently introduced. After all, we think our investigation is timely. It is, therefore, necessary to explore the meaning of the concept such as fair play, and the positive moral values it conveys in the dictionary and values of young people.

The fact that immeasurable corruption, violence, and greed prevail in Kenya and Malaysia is almost well known, and several studies have substantiated its effects on the rising generation. We would highlight Robb's research first, which concluded that although young people recognize the need to learn values, they do not consider it worthwhile in the long run. Arthur already mentions moral panic over the destructive behavior and moral deterioration of young people in Malay society. Rahman points out that everything is based on immeasurably high levels of public corruption, which cripples people.

A similar situation prevails in Kenya. Rising generations are seeing that corruption is already left without tradition and punishment. In addition, the constant acts of terrorism exemplify the advancement of aggression and violence. Equality cannot be achieved within the education system.

Regarding the selection of role models based on both international and domestic studies. the following trend is observed. Initial research on the subject concluded that young people chose mainly historical and literary figures as role models, by 1955 this proportion was only 10\%. Based on international surveys in 2000, it can already be stated that young people choose a person of orientation from the world of pop music, sports, or cinema. In this, the spread of Internet use plays a key role in the media. We can get a similar result in Hungary. In the 2000s, young people chose a role model from their immediate environment and represented value for them, eg actor János Gálvolgyi. From 2007, the role of the media became more and more noticeable and the celebrities who appeared there were given priority. This trend continues to this day. And the question arises as to where and how to proceed if, for young people, traditional values are no longer values.

\section{TEST AND METHODS}

\section{Hypothesis}

$H_{1}$ : It is assumed that most of young people have an athlete role model.

$\mathrm{H}_{2}$ : It is assumed that in Kenya and Malaysia there is a significantly higher proportion of those who choose athlete role models and they are chosen along with positive values.

$H_{3}$ : It is assumed that, due to social, economic, and cultural disparities, I can show significant differences in the choice of role models for young people surveyed in Central and Eastern European and non-European countries.

\section{Sampling Procedure and Circle of those Involved in the Study}

As a research method, we used the questionnaire. The questionnaire contained 18 questions, of which 15 were closed and 3 were open-ended. 669 individuals from the six countries participated in the survey. The six countries were Hungary $(n=126)$, 
Kenya $(\mathrm{n}=205)$, Malaysia $(\mathrm{n}=60)$, Ukraine $(\mathrm{n}=$ $165)$, Romania $(n=44)$ and Serbia $(n=87)$. In the course of the analysis, not only the individual countries were examined separately, but two groups were formed based on the above, thus Central and Eastern European $(\mathrm{n}=405,60.50 \%)$ and nonEuropean $(n=264,39.50 \%)$ countries were also compared if the merging of the countries was also professionally justified. As some countries were not equally represented, the sample number for the characteristics of each country remained in the comparison, but I used arithmetic averages. Due to the low sample number of the Romanian data, its findings need to be analysed with caution, as no conclusion can be drawn for the larger population. However, due to the internationality of the research, I decided to leave it in the analysis. Of the respondents, 397 were women $(59.30 \%)$ and 272 were men $(40.70 \%)$, ranging in age from 10 to 30 years $($ mean $=17.19$, standard deviation $=4.47)$. During the analysis, we examined the participants in two age groups: 1 ) primary school students $(\mathrm{n}=327$, $48.9 \%$ ) and 2) students participating in higher education $(\mathrm{n}=342,51.10 \%)$. Examining the gender ratio, we can state that the proportion of girls (48.90\%, 160 people) and boys $(51.10 \%, 167$ people) among primary school students was almost the same, but in the case of university students participating in higher education, women $(69.30 \%$, 237 people) was in a significant majority compared to men $(30.70 \%, 105$ people).

During the data collection, it was not possible to interview the entire population, so a sampling procedure was carried out, during which we selected the selected part of the population, in this case, 1015-year-old (Z) primary school students and 17-30 (Y)-year-old undergraduate and college students. Data collection procedure and scope of the study 669 individuals from 6 countries participated in the survey (Table 1).

Table 1: Gender distribution in the six countries and the combined groups of Central and Eastern European and non-European countries

\begin{tabular}{llllll}
\hline & Woman \% (persons) & Man \% (persons) & & $\begin{array}{l}\text { Woman } \\
\% \\
\text { (persons) }\end{array}$ & $\begin{array}{l}\text { Man \% } \\
\text { (persons) }\end{array}$ \\
\hline Hungary & $61.20(74)$ & $38.80(47)$ & & & \\
Ukraine & $53.00(87)$ & $47.00(77)$ & Central and Eastern 64.40 & 35.60 \\
Romania & $85.30(29)$ & $14.70(5)$ & European countries & $(261)$ & $(144)$ \\
Serbia & $82.60(71)$ & $17.40(15)$ & & & \\
\hline Kenya & $52.50(107)$ & $47.50(97)$ & Non-European countries & 51.50 & 48.50 \\
Malaysia & $48.30(29)$ & $51.70(31)$ & & & $(136)$ \\
\hline
\end{tabular}

Looking at the age groups for the six countries, it is important to note that Romania and Serbia lacked the age group of primary school students aged 1015 , and Malaysia lacked the age group of university students aged 18-30. In Hungary, university students, in Kenya, primary school students were in the majority, and in Ukraine, the two age groups accounted for almost half to half (Table 2). In the case of Central and Eastern European and nonEuropean countries, the proportion of age groups showed a statistical difference $\left(\chi^{2}(1)=102.44\right.$, $p$ $<0.001)$. In Central and Eastern European countries university students, while in non-European countries, primary school students were in a significant majority. 
Table 2: Distribution of primary and university students in the six countries and the combined groups of Central and Eastern European and non-European countries

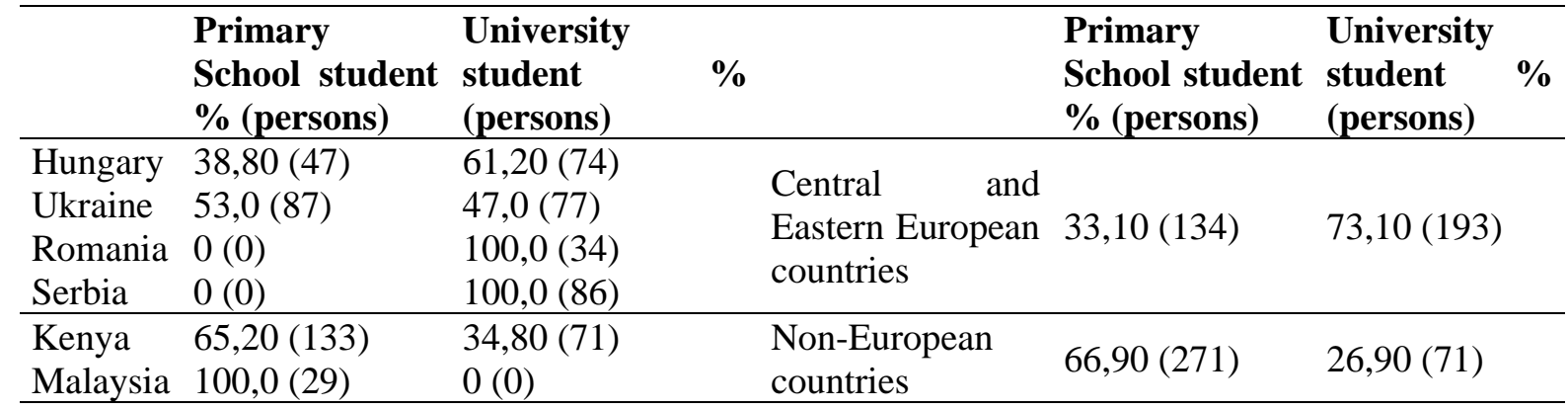

Source: Own editing

In accordance with the above results characterizing the sample, we also examined the differences between men/boys and women/girls, as well as the differences between the two age groups. When comparing the six countries as well as Central and Eastern European and non-European countries, the existing gender and age differences were also taken into account in order to be able to precisely determine the differences between countries due to geographical location or differences in background variables such as gender and age group.

\section{Presentation of Applied Study Methods}

As a descriptive statistical indicator, the mean and standard deviation data were indicated for scale variables, and the frequency data (\%, persons) for categorical variables. Comparison of two independent samples along a scale variable was performed with a 2-sample t-test, and if the condition of standard deviation homogeneity was not met, we inferred from the results of the Welch d-test. Comparisons of more than two independent samples were performed by one-way analysis of variance, and if the condition of standard deviation homogeneity was not met, we inferred from the results of the robust Welch d-test. Among the post hoc tests of the pairwise comparison, Tukey's HSD test was used if the condition of equality of variances was met. In addition to the inequality of variances, the results of the Games-Howell test were taken into account. The effect of more than two independent variables on one dependent variable (scale variable) was examined by two-way analysis of variance, assuming an interaction between the independent variables included in the model. The independence of two nominal and/or ordinal variables was performed by cross-tabulation analysis. Fisher's exact test was used for $2 \times 2$ crosssections, and Pearson's chi-square statistics were used for cross-sections larger than $2 \times 2$. If the conditions for the application of the cross-tabulation analysis (expected frequency of at least 1 for each category and no more than $20 \%$ of the categories with an expected frequency of not less than 5) were not met, the frequency data were compared descriptively. During the statistical analysis, the recorded significance level was $\mathrm{p}=0.05$ or $\mathrm{p}=$ 0.001 , and the data are significant if the condition of having $99 \%$ or $95 \%$ validity is met.

Statistical analyses were performed using IBM SPSS 20 statistical software (IBM SPSS Statistics, IBM Corporation, Chicago, IL).

\section{RESULTS}

Overall, nearly half of the survey participants indicated that they have $(54.30 \%, 363$ people) and do not have $(45.70 \%, 306$ people) an athlete role model. A significantly higher proportion of boys/men $(69.50 \%, 189$ people) were characterized by having an athlete role model compared to girls/women $\left(43.80 \%, 174\right.$ people) $\left(\chi^{2}(1)=42.81\right.$, $\mathrm{p}<0.001)$. The age groups also showed a significant difference in this proportion, $70.30 \%$ of primary school students (230 people) and $38.90 \%$ (133 people) of university students indicated that they have an athlete role model $(\chi 2(1)=66.61, \mathrm{p}$ $<0.001)$. Furthermore, when examined separately in the two age groups, it was found that both among primary school students $(\chi 2(1)=10.75, \mathrm{p}=0.001)$ and among university students $\left(\chi^{2}(1)=17.04, \mathrm{p}\right.$ 
$<0.001)$ a higher proportion of boys/men have an athlete role model compared to girls. (Figure 1.)

Our results are also supported by our literature research. French and Pena, in their study examining the gender difference, found that boys named men, athletes, pop stars, television actors, actors as their role models, while girls named movie stars, pop stars, and relatives of the opposite sex.

Biskup and Pfister came to a similar conclusion, with their research subjects, most notably boys, often choosing athletes as role models. Most boys choose athletes and action heroes because they consider them aggressive, strong, and capable of anything. In contrast, girls prefer the movie or pop stars because they like their appearance or social behaviour.

Regarding girls, we can rely on the research of Lines , which showed that girls are much more likely to choose role models from magazines or the television screen.

Figure 1: Athlete role models among primary school and university student boys/men and girls/women

Doesn't have role modell

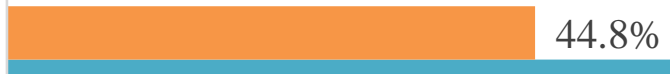

\section{$44.8 \%$}

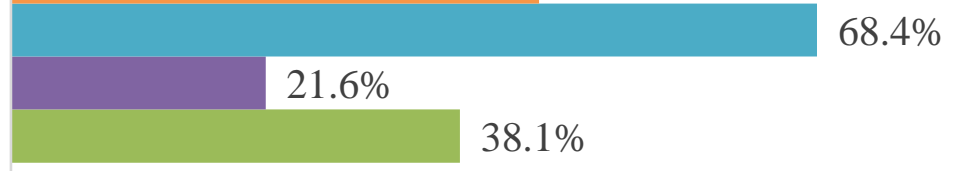

Has role model
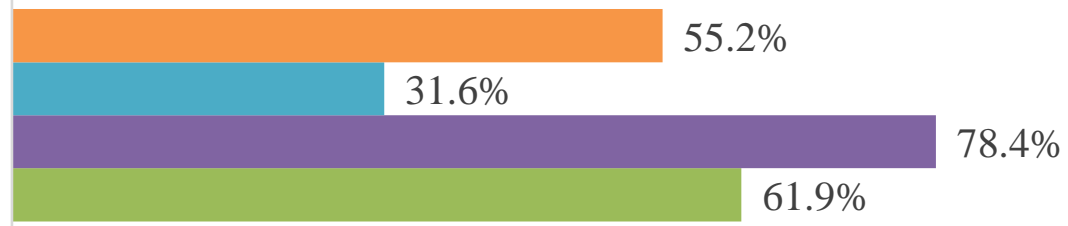

$\begin{array}{llllllllll}0 & 10 & 20 & 30 & 40 & 50 & 60 & 70 & 80 & 90\end{array}$

- University student Boy/man

Primary school student Boy/man
- University student Girl/woman

Primary school student Girl/woman
Examining the six countries, it can be stated that Kenya $(85.30 \%, 174$ people) and Malaysia $(80 \%, 48$ people) have a significantly higher proportion of people with an athlete role model $\left(\chi^{2}(5)=174.14\right.$, $\mathrm{p}<0.001)$, in Hungary $(40.50 \%, 49$ people) and Ukraine $(42.10 \%, 69$ people) the proportion of those who have/do not have an athlete role model is almost half-half, while Romania ( $23.50 \%, 8$ people) and Serbia $(17.40 \%, 15$ people) have the smallest number of people who have an athlete role model. (Figure 2.) 
Figure 2: Athlete role models in the countries surveyed

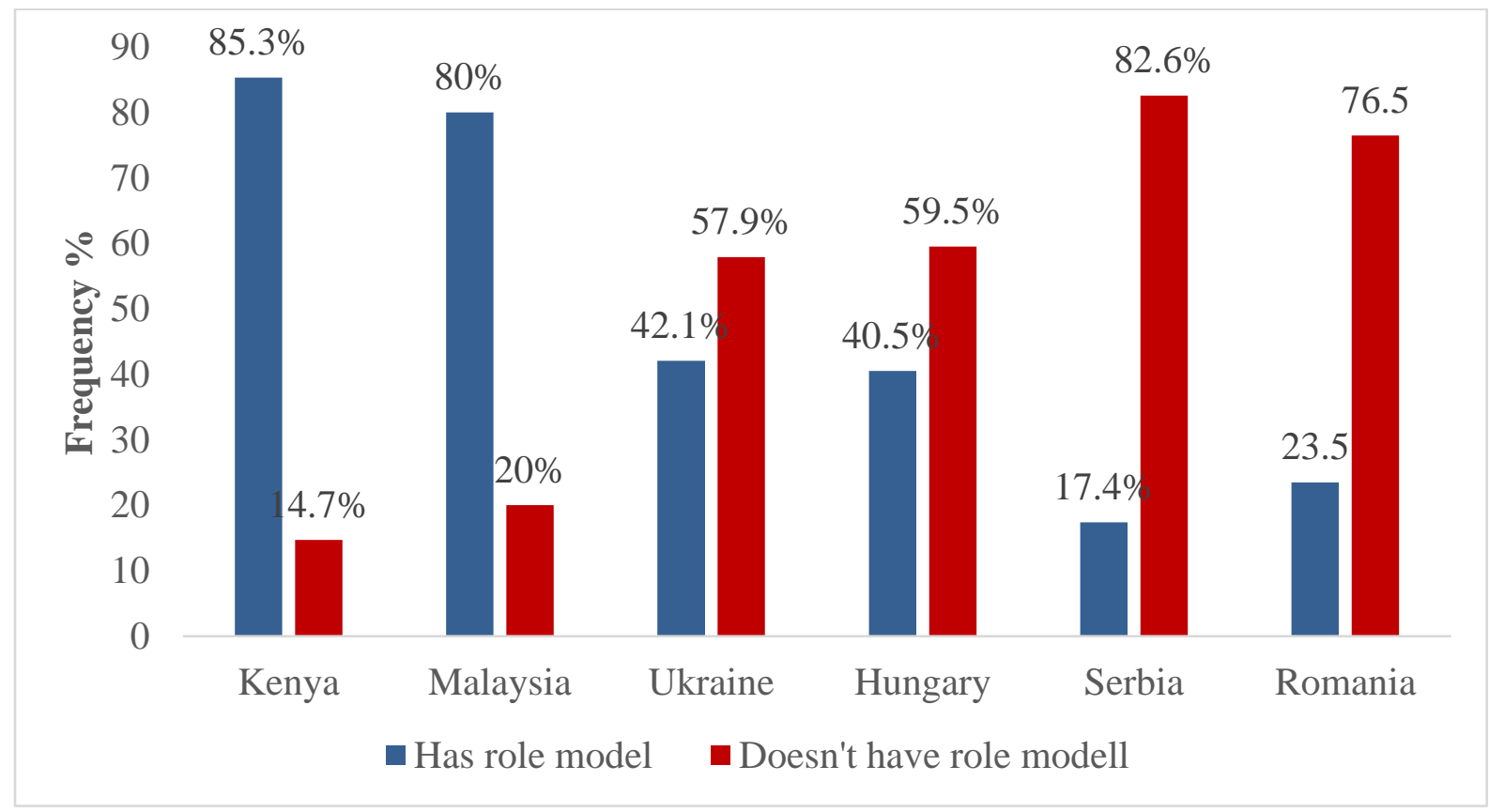

Taking into account the gender differences, we found that regardless of gender, both women/girls $\left(\chi^{2}(1)=110.83, \mathrm{p}<0.001\right)$ and men/boys $\left(\chi^{2}(1)=\right.$ $40.29, \mathrm{p}<0.001)$ in non-European countries have a higher proportion of athlete role models. For women, the proportion is $80.10 \%$ (109 people) in non-European countries and $24.90 \%$ (65 people) in Central and Eastern European countries. Among men, $88.30 \%$ (113 people) indicated this in nonEuropean countries, while $52.80 \%$ (76 people) in European countries.

Examining the age groups based on our results, regardless of the age group, both primary school students $\left(\chi^{2}(1)=55.46, \mathrm{p}<0.001\right)$ and university students $(\chi 2(1)=60.28, p<0.001)$ in non-European countries have a higher proportion of athlete role models than Central and Eastern European countries. In primary schools, $86 \%$ (166 people) in non-European countries have an athlete role model, compared to $47.80 \%$ (64 people) in European countries. Among university students, $78.90 \%$ (56 people) in non-European countries and $28.40 \%$ (77 people) in Central and Eastern European countries indicated this.

Overall, a comparison of Central and Eastern European and non-European countries shows that, regardless of gender and age group, in nonEuropean countries, people are more likely to choose an athlete role model than in European countries. (Figure 3.) 
Figure 3: Athlete role models by gender and age group in Central and Eastern European and nonEuropean countries

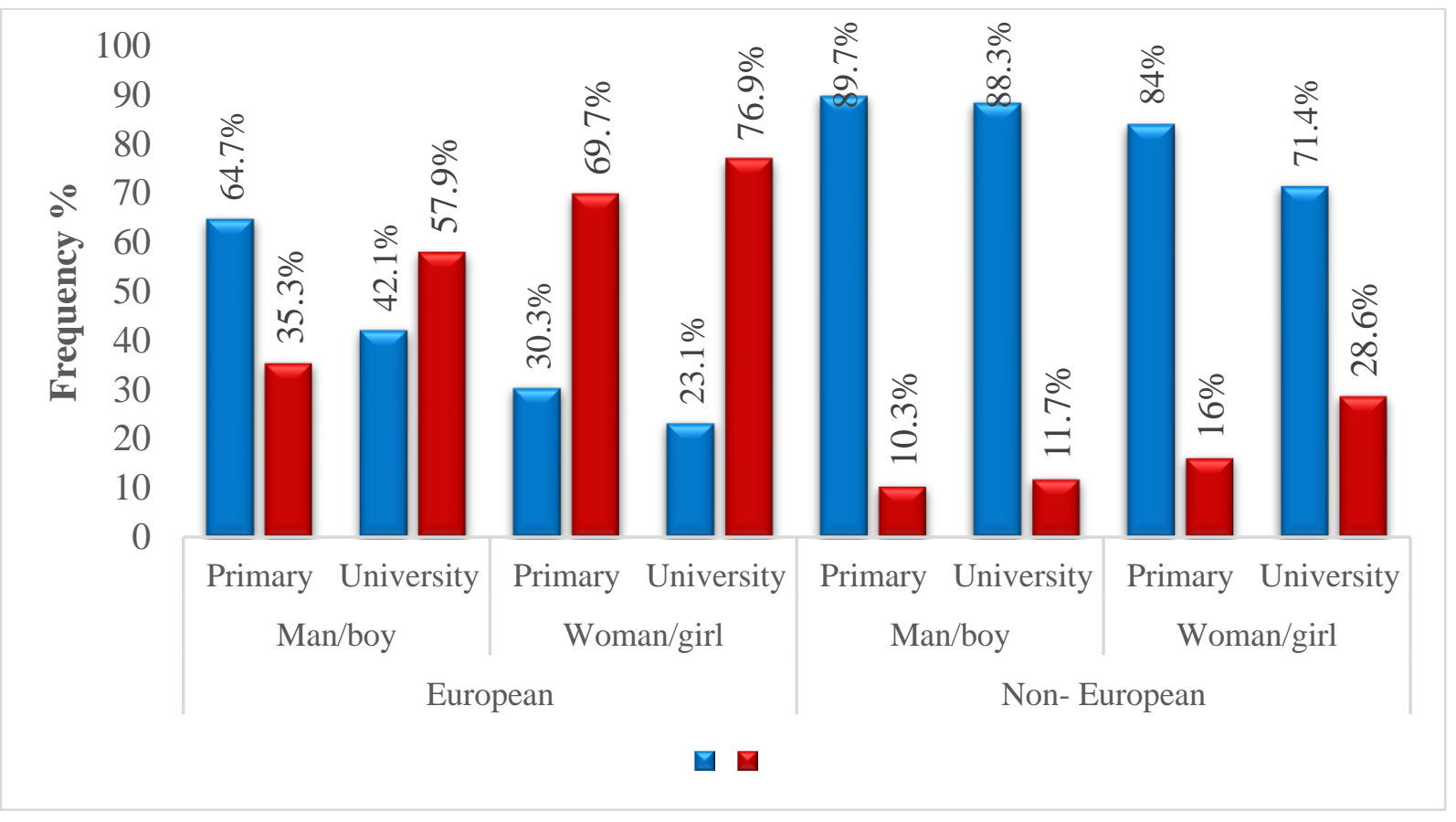

Source: Own editing

In the case of choosing an athlete role model, we also asked for the name of the given role model. It is worth noting that, overall, among those who indicated that they had an athlete role model, $89.30 \%$ (324 people) were able to name their role model, and of those who did not otherwise indicate that they had an athlete role model, 11 were able to name such a role model. The naming of the role models was completely heterogeneous, with the names of 134 athletes given. The most frequently mentioned athletes include Ronaldo (11\%, 37 people) and Messi (11.60\%, 39 people), several more indicated Neymar $(4.80 \%, 16$ people) and Lee Chong Wei (4.80\%, 16 people).

When choosing the role models, the participants also had to indicate the qualities based on which they selected the role model, where they could choose from 9 listed qualities (selfless, modest, disciplined, has the outstanding professional knowledge, aggressive, courageous, selfish, rude) as well as they could indicate other qualities. The results were examined in aggregate, including the answers of those who gave a "no" answer to the previous question, which means they did not have a role model. A total of 627 people chose a quality $(93.70 \%)$.

The most frequently chosen qualities were outstanding professional knowledge $(38.60 \%, 242$ people) and selflessness (16.60\%, 104 people). The choice of qualities showed a heterogeneous picture, so in further analysis, we created 4 categories: 1 . professional knowledge, 2. selflessness, 3. additional positive qualities, and 4 . negative qualities (Table 3). The categories were formed ourselves because it was not methodologically justified to perform a factor analysis, given that each respondent could only mark one quality and the KMO value and the running of the Barnet test did not show a realistic result, so no well-interpreted factors came out. We would note that selflessness is also a positive quality, but we have placed it in a separate category, as it was chosen by the highest proportion of young people, as well as outstanding professional knowledge. Other responses $(1.80 \%$, 11 people) were excluded. It is important to note that selflessness was placed in a separate category as a positive value because it was indicated by most and considered worthy of being treated as a separate category

124 | This work is licensed under a Creative Commons Attribution 4.0 International License. 
International Journal of Advanced Research, Volume 3, Issue 1, 2021

Article DOI: https://doi.org/10.37284/ijar.3.1.400

Table 3: Qualities of an athlete role model in the total sample $(N=627)$

\begin{tabular}{llll}
\hline Role model qualities & \% (people) & Quality categories & $\%$ (people) \\
\hline Outstanding professional knowledge & $38,60(242)$ & professional knowledge & $39,30(242)$ \\
\hline Selfless & $16,60(104)$ & selflessness & $16,90(104)$ \\
\hline Modest & $12,10(76)$ & & \\
Disciplined & $11,30(71)$ & & \\
Brave & $10,70(67)$ & additional positive qualities & $35,90(221)$ \\
Persistent & $0,60(4)$ & & \\
Dedicated & $0,30(2)$ & & \\
Able to lose & $0,20(1)$ & & \\
\hline Aggressive & $2,40(15)$ & & \\
Selfish & $3,80(24)$ & negative qualities & \\
Rough & $1,60(10)$ & & \\
\hline Other & $1,80(11)$ & & \\
\hline
\end{tabular}

Each quality category showed a statistically significant difference between men/boys and women/girls $\left(\chi^{2}(3)=8.89, \mathrm{p}=0.031\right)$. A higher proportion of men/boys indicated outstanding professional knowledge $(46.20 \%, 116$ people) than women/girls $(34.50 \%, 126$ people). A higher proportion of women/girls indicated selflessness (18.90\%, 69 people) and additional positive qualities $(38.10 \%, 139$ people). For men/boys, the proportion of these was $13.90 \%$ (35 people) and $32.70 \%$ (82 people), respectively. The choice of negative traits was nearly identical between the two sexes. Negative qualities were reported by $8.50 \%$ of women/girls (31 people) and $7.20 \%$ of boys/men (18 people).

Based on age groups, the property categories also showed a statistically significant difference $\left(\chi^{2}\right.$ (3) $=25.58, \mathrm{p}<0.001)$. A higher proportion of primary school students $(45.80 \%, 142$ people) indicated outstanding professional knowledge than university students $(32.70 \%, 100$ people). A higher proportion of university students indicated additional positive qualities $(45.10 \%, 138$ people) compared to primary school students $(26.80 \%, 83$ people). Although overall negative qualities were marked by few as characteristics of the chosen role model, a higher proportion of those who marked it were primary school students $(10.30 \%, 32$ people) than university students $(5.60 \%, 17$ people). The perception of selflessness was nearly the same in the two age groups studied. Selflessness was reported by $17.10 \%$ of primary school students (53 people) and $16.70 \%$ of university students (51 people). Judging of age groups and quality categories examined separately showed the same results among boys/men and girls/women.

Comparison of Central and Eastern European and non-European countries resulted in a statistically significant difference in the proportion of quality categories $\left(\chi^{2}(3)=99.09, \mathrm{p}<0.001\right)$. In nonEuropean countries, the proportion of those who indicated outstanding professional knowledge was significantly higher $(59.10 \%, 153$ people) compared to Central and Eastern European countries (24.90\%, 93 people). For other positive qualities, the proportion of those indicating was higher in Central and Eastern European countries (51.20\%, 191 people) than in non-European countries $(16.20 \%, 42$ people). The proportions of selflessness and negative qualities did not differ significantly. Selflessness was reported by $17.40 \%$ (65 people) in Central and Eastern European countries and 15.10\% (39 people) in non-European countries. Finally, negative qualities were reported by $6.40 \%$ (24 people) in European countries and 9.70\% (25 people) in non-European countries.

Taking into account gender differences, based on our results, the differences observed above between Central and Eastern European and non-European countries were gender independent. Both men/boys $\left(\chi^{2}(3)=41.98, \mathrm{p}<0.001\right)$ and girls/women $\left(\chi^{2}(3)\right.$ $=57.54, \mathrm{p}<0.001)$ showed that Central and Eastern European countries considered other positive qualities, and non-European countries considered outstanding professional knowledge to be a more attractive characteristic of an athlete role model. It is also worth noting that among women/girls, 
negative characteristics were marked by a significantly higher proportion of people living in non-European countries $(12.50 \%, 17$ people) compared to those living in Central and Eastern European countries $(5.80 \%, 14$ people). Among men/boys, no such difference was observed for negative qualities.

Examining the age groups, our results showed that in the case of both primary school students $(\chi 2(3)=$ $69.85, \mathrm{p}<0.001)$ and university students $\left(\chi^{2}(3)=\right.$ 13.64, $\mathrm{p}=0.003)$ a higher proportion of people living in Central and Eastern European countries indicated other positive qualities, while a higher proportion of people living in non-European countries indicated outstanding professional knowledge. The proportion of selflessness and negative qualities was almost the same among Central and Eastern European and non-European university students and primary school students. However, in the case of age groups, the difference observed in the two examined groups of geographical location is not independent of gender.
In the case of primary school students, we experienced the difference among both men/boys $(\chi 2(3)=31.38, \mathrm{p}<0.001)$ and girls/women $(\chi 2(3)$ $=45.44, \mathrm{p}<0.001)$ living in Central and Eastern European and non-European countries, which means that primary school students living in European countries preferred other positive qualities regardless of gender, while those living in non-European countries chose outstanding professional knowledge more as a characteristic of an athlete role model. It is also worth noting that a higher proportion of primary school girls living in non-European countries indicated a negative quality $(14.90 \%, 14$ people) compared to their counterparts in Central and Eastern European countries (8.60\%, 5 people). However, among university students, the difference in the perception of qualities between European and non-European countries was characteristic only for men $(\chi 2(3)=8.97, p=0.03)$, while female students marked each quality category in almost equal proportions regardless of geographical location $\left(\chi^{2}(3)=6.26, \mathrm{p}=0.100\right)$.

Figure 4: Judging the qualities of an athlete role model by gender and age group in Central and Eastern European and non-European countries

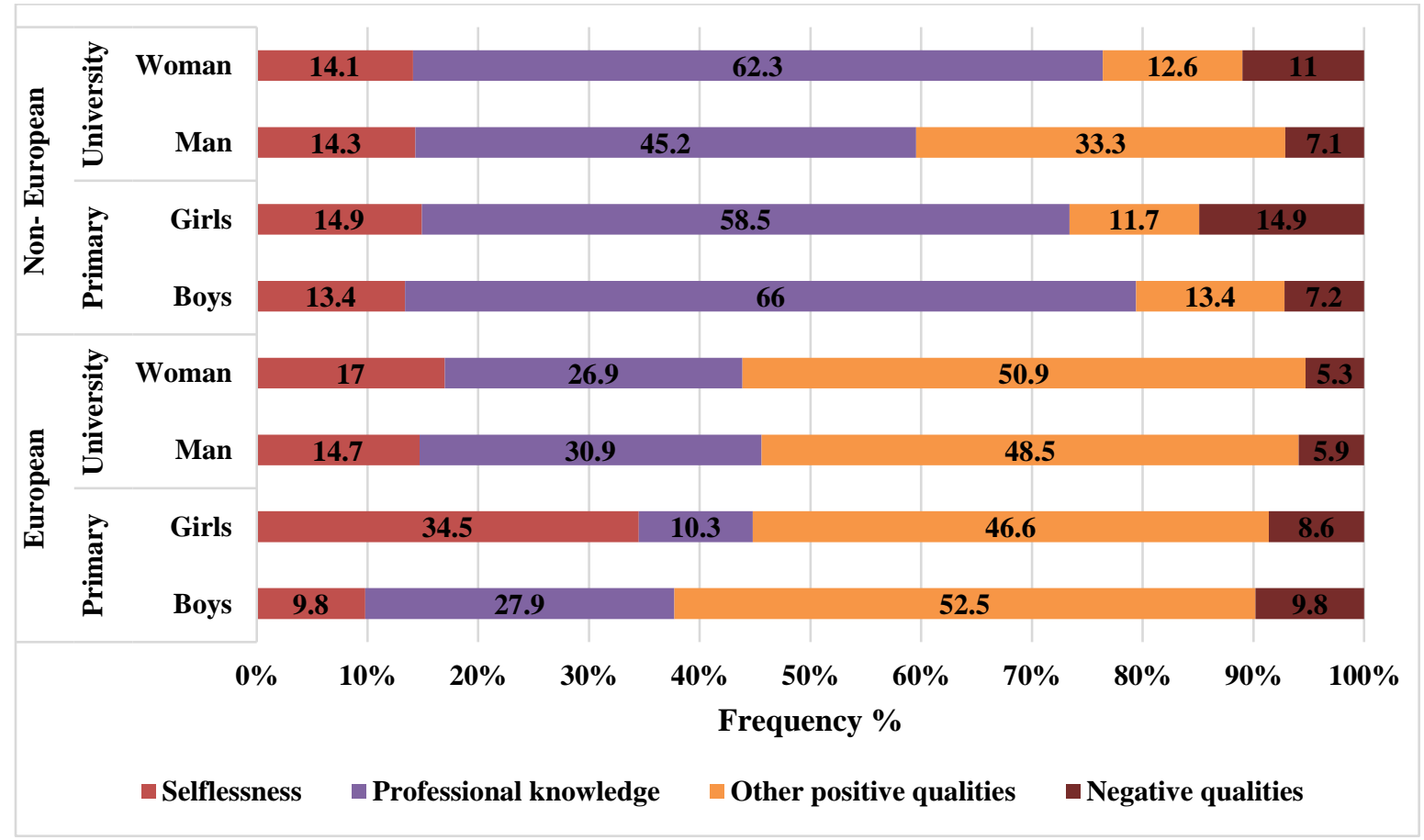

Source: Own editing

126 | This work is licensed under a Creative Commons Attribution 4.0 International License. 
Overall, a comparison of Central and Eastern European and non-European countries shows that in non-European countries it is more common to choose an athlete role model primarily because of outstanding professional knowledge, while in Central and Eastern European countries the athlete role model is mainly chosen for other positive qualities such as modesty, discipline, courage. This correlation was independent of gender in primary school age, however, it was characteristic only among men within the older age group, while in the case of women such an effect of geographical differences was not observed (Figure 4.).

\section{Hypothesis Testing}

H1: It is assumed that most of young people have an athlete role model. Based on our results, this assumption has been proven. We can see overall, nearly half of the survey participants indicated that they have and do not have an athlete role model. A significantly higher proportion of boys/men were characterized by having an athlete role model compared to girls/women.

$\mathrm{H} 2$ : It is assumed that in Kenya and Malaysia there is a significantly higher proportion of those who choose athlete role models and they are chosen along with positive values. This assumption has been proven because Kenya (85.30\%, 174 people) and Malaysia ( $80 \%, 48$ people) have a significantly higher proportion of people with an athlete role model $(\chi 2(5)=174.14, p<0.001)$, in Hungary (40.50\%, 49 people) and Ukraine $(42.10 \%, 69$ people) the proportion of those who have/do not have an athlete role model is almost half-half, while Romania (23.50\%, 8 people) and Serbia (17.40\%, 15 people) have the smallest number of people who have an athlete role model.

H3: It is assumed that, due to social, economic, and cultural disparities, I can show significant differences in the choice of role models for young people surveyed in Central and Eastern European and non-European countries. Based on our results, this assumption has been proven. Overall, a comparison of Central and Eastern European and non-European countries shows that, regardless of gender and age group, in non-European countries, people are more likely to choose an athlete role model than in European countries.

\section{CONCLUSION}

Based on our results, this assumption has also been proven. We found that Kenya and Malaysia had a significantly higher proportion of those with an athlete role model. This may be due to the fact that the role model in the lives of young people in Kenya and Malaysia is a successful person who presents the possibility of ascension/eruption more important than young people for whom the world has expanded through economic and technological development.

We think this is due to the reasons highlighted in our theoretical framework. Notably, unemployment and corruption are high in both countries, and equal opportunities are not being realized within the education system, which should ensure the possibility of catching up and breaking out. In fact, a young person drops out of school for years because his family has to consider teaching the child and thus losing a breadwinner, not to mention that education, despite being free, comes at a serious cost. In light of this, athletes who are successful and earn a lot of money - at least as much as these young people cannot even dream of - appear as role models. They have the potential and hope to break out, which is why the sport is especially popular in these countries.

If we examine the qualities on the basis of which young people choose role models, we see that they look up to athletes primarily because of their outstanding professional knowledge, and the second most popular response is that they are selfless. Negative qualities are displayed in minimal numbers. The interesting thing about this is that young people who chose based on negative qualities (aggressive, rude, selfish) are typically named martial arts athletes.

The responsibility of role models, "people living in shop windows" today is enormous, which is often overlooked. By giving extreme examples, can such people really be seen as role models who have been tattooed from head to toe, athletes who get involved in tax fraud, who consume alcohol and drugs, and often cause accidents under their influence? Undoubtedly, their professional performance may be outstanding, their appearance may be attractive, but they are by no means to be followed. Their 
responsibilities are enormous, which we do not think they would be aware of. And to draw attention to this is the responsibility of society. After all, knowing such a selection of role models, where scandals are often the goal, how can we expect young people to be aware of the spirit and fair values of fair play if the values conveyed by the chosen orientation person are not traditional? The question may arise, do young people need to set an example at all?

By the end of our research, it became clear that the first field of socialization is the family, children first acquire the values they see and learn there, we considered it important to explore the values - from Hungary and the "world" - along which a young person develops his own moral and value perceptions. In our opinion and experience, traditional family models and their values now seem to be disintegrating, women are increasingly having children later, and in many cases, a career which helps to build a secure existence becomes more important, or at least ahead of time to have children. Traditional husband/father and wife/mother roles in families change, swap, a number of marriages, decreases, divorces increase. Single-parent or mosaic families are becoming more common, creating conflicts, thereby increasing insecurity, and leading to frustration.

\section{REFERENCES}

Arthur, J. 2003. Education with Character: The Moral Economy of Schooling. London: Routledge.

Berta, J. 2008. "A szocializációs ágensek hatása a példaképválasztásra." Új Pedagógiai Szemle 58(6-7): 64-78.

Biskup, C., and G. Pfister. 1999. "I would like to be her/ him: Are athletes role models for boys and girls?" European Physical Education Review, 5(3): 199-218.

Ewens, W., and M. Lashuk. 1989. "Role model identification and activity preferences of Australian youth." The ACHPER National Journal 125(2): 18-20.

Fitzclarence, L., and C. Hickey. 1998. "Learning to rationalise abusive behaviour through football
Where the boys are: Masculinity, sport and education." In Where the boys are: Masculinity, sport and education, edited by C. Hickey, L. Fitzclarence and R. Matthews. Geelong, Deakin University Press.

French, J., and S. Pena. 1991. "Children's hero play of the 20th century: Changes resulting from televisions influence." Child Study Journal 21(2): 79-95.

Havighurst, R. J., and D. V. Mcdonald. 1955. "Development of the ideal self in New Zealand and American children." Journal of Educational Research 49:4: 263-273. doi: http://dx.doi.org/10.1080/00220671.1955.10882 281.

Hill, D. S. 1930. "Personification of Ideals by Urban Children." The Journal of Social Psychology 1:3: 379-393. Accessed 02. 23., 2021. doi: https://doi.org/10.1080/00224545.1930.971414 4.

Ilic, J. 2013. "Sports Idols of Senior Athletes." SportLogia 9(1): 8-14.

László, M. 2010. Példakép kutatások 2000-2009. Budapest: Alkalmazott Kommunikációtudományi Intézet. https://adoc.pub/queue/peldakepkutatasok.html.

Lines, G. 2001. "Villains, fools or heroes? Sports stars as role models for young people." Leisure Studies 20(4): 285-304.

Mihály, I. 2006. "Hősfogyatkozás" vagy modellterror? Új Pedagógiai Szemle, 56(1) pp. 113-119 p." Új Pedagógia Szemle 56(1): 113119. Accessed 04. 02, 2021. http://epa.oszk.hu/00000/00035/00099/200601-vt-Mihaly-Hosfogyatkozas.html.

Pap, K. 2015. "A példaképek és a fogyasztói magatartás vizsgálata a 10-14 éves korosztály körében." In Marketing hálózaton innen és túl, edited by Sz. Bíró-Szigeti, I. Petruska, Zs. Szalkai, I. Kovács and M. Magyar, 257-265. Budapest: Budapesti Müszaki és Gazdaságtudományi Egyetem. 
Rahman, A. 2014. "Values Education and the Malaysia Education Blueprint." Journal of Interdisciplinary Research in Education (JIRE) 4(1): 59-73.

Reymert, M. L. 1916. "Zur Frage nach den Idealen des Kindes." Zeitschrift für pädagogische Psychologie 17(2): 226-250.

Robb, W. 1998. "What is values education- And so what?" The Journal of Values Education 1(1): 113.

Teigen, K. H., E.-H. T. Normann, J. O. Bjorkheim, and S. Helland. 2000. "Who would you most like to be like? Adolescents' ideals at the beginning and the end of century. Scandinavian Journal of Educational Research, 20(1)." Scandinavian Journal of Educational Research 20 (1): 5-26. Accessed $02 . \quad 12 ., \quad 2021$. doi:10.1080/713696661. 